\title{
Flickr Photos Analysis for Beach Tourism Management in Bantul Regency, Indonesia: Popularity and Tourist Attractions
}

\author{
Arief Wicaksono *, Nur Mohammad Farda, Nurul Khakhim, Totok Wahyu Wibowo \\ Faculty of Geography, Universitas Gadjah Mada, Sekip Utara, Bulaksumur, Yogyakarta 55281 \\ *) Corresponding Author (e-mail: wicaksono.arief08@gmail.com)
}

Received: 24 December 2020/ Accepted: 31 May 2021 / Published: 24 August 2021

\begin{abstract}
Photos shared by social media users act as an approach in identifying tourist activity. Popular tourist attractions are judged based on the large number of photos or high photo density. In Bantul Regency, Indonesia, beaches have diverse attractions which tourists can enjoy and immortalize through photos. Analyzing the contents of photos on Flickr provides information on the type(s) of beaches or coastal attractions preferred by tourists. This study examined the availability of geotagged Flickr photos to assist in making relevant beach tourism management policies. It employed pattern analysis with the average nearest neighbor, density analysis with kernel density estimation, image content analysis with tourist attraction as the variable, and overlay analysis to formulate recommendations for beach tourism management based on the popularity level of the attractions. The results indicate that each of the local beaches offers different attractions with varying popularity levels and that natural beauty is the main feature attracting tourists to visit all beaches, except Baros. Based on the pattern analysis, the Flickr photos are clustered on several beaches of high popularity, such as Parangtritis, Baros, Depok, and Cemara Sewu. By using geotagged Flickr photo data and refers to the concept of tourism supply and demand, recommendations for developing the attractive features on these beaches have been compiled according to their respective themes and popularity levels to target specific tourist market segments and design integrated tour or travel packages.
\end{abstract}

Keywords: Popularity, Beach, Tourist Attraction, Image Content Analysis, Flickr.

\section{Introduction}

The development of participatory mapping in Indonesia began with the resolution of agrarian conflicts, then evolved into digital participatory mapping (VGI) with a larger number of participants (Safitri and Pramono, 2009). Web 2.0 gave rise to the term Traveller 2.0, which is characterized by tourists sharing their travel experiences (via text and multimedia) and disseminating them via theinternet(Parra-Lopezetal.,2012). On the next-generation of Web 3.0, apart from enabling interaction between internet users and information providers, it can also share data so that internet users currently act as producers and providers of data and information (Yudono, 2017). Social media analysis is a framework for data acquisition, processing, and data analysis to find hidden patterns and gain knowledge from the visualization of these hidden patterns (Thelwall, 2018). Social media can be used to support tourism management because its role in the tourism industry can be observed from the pre-trip to post-trip stages (Chung and Buhalis, 2008). Garrod (2009), Lo et al. (2011), and Stylianou-Lambert (2012) state that there is a relationship between tourism and photos, even Tenkanen et al. (2017) states that there is a correlation between geotagged photos and tourist visits. Photos circulating in cyberspace, whether shared by netizens or travel promotion accounts, can affect the image / views of these sites in the community (MacKay and Couldwell, 2004; Castro et al., 2007; Urry and Larsen, 
2011; Camprubí et al., 2013; Alonso-Almeida et al., 2019) so as to motivate people to visit these beaches (Hall and Page, 2006).

\section{0 millions}

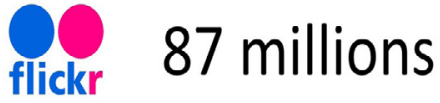

\section{$\stackrel{\oplus}{\text { Rengemio }} 4$ millions}

Figure 1. Number of Social Media Users Worldwide (Stock, 2018).

Several social media that are able to share photos, for example Instagram, Flickr, and Panoramio, have a large number of users around the world (Figure 1). Photos shared by social media users are used as an approach in identifying tourist activity at sites in a spatially-temporal manner (Wibowo et al., 2019). Information on which locations are most frequently visited by tourists is obtained from the number of photos uploaded by tourists to social media. Panoramio has stopped operating since November 2016 (Ghermandi and Sinclair, 2019), while the Instagram API has been restricted since December 2018 (Rofi'i et al., 2019; Ghermandi and Sinclair, 2019) so that both social media cannot be used to retrieve the latest geotagged photos data for free. Thus, Flickr was chosen as the source of research data on the grounds of the availability of a relatively long database (operating since 2004) (Li et al., 2018), dominant geotagged photo data (Bae and Yun, 2017), and ease of accessing data through open APIs (Public API) (Ghermandi and Sinclair, 2019). Several social media studies for tourism that use Flickr as a data source, including Kisilevich et al. (2010) and Wibowo et al. (2019) regarding the identification and comparison of spatiotemporal patterns of tourist activity, Donaire et al. (2014) on the identification of various tourist groups, Peng and Huang (2017) on the identification of popular tourist attractions, Yan et al. (2017) regarding monitoring and assessment of post- disaster tourism recovery conditions, and Ding and Fan (2019) regarding a study of semantic and spatial distribution patterns of tourism objects.

Bantul Regency is a tourism destination with the most visits in Special Region of Yogyakarta Province (DIY) (Dinas Pariwisata DIY, 2019), with the most popular tourist attraction being the beach (BPS Kabupaten Bantul, 2020). Figure 2 presents a graph of the number of visitors to the five most popular beaches in Bantul Regency in 2015-2019. Parangtritis and Samas Beach are the tourist attractions in Bantul Regency which are most visited by tourists (Dinas Pariwisata DIY, 2018). In the last 5 years (2015-2019), the number of visits to tourism objects in Bantul Regency has fluctuated and tends to decrease. This condition is even more worrying because since early 2020 there have been restrictions on tourism activities to prevent the spread of the Covid-19 virus in Bantul Regency. The development of tourism according to Hardjowigeno and Widiatmaka (2017) is influenced by the potential of the tourist attraction offered and the amount of tourist demand. This study adopts the concept of supply and demand for tourism (Hall and Page, 2006) as a basis for managing beach tourism.

Hall and Page (2006) explain the concept of supply and demand for tourism in the tourism industry. Tourism supply is all the activities of producing goods and services required in tourism in the form of tourism consumption, such as tourism resources, tourism facilities, entertainment and sports venues, and tourism revenue services. Tourism demand from a geographic point of view is the total number of people traveling, or wanting to travel, to use tourism facilities and services. Hardjowigeno and Widiatmaka (2017) explain that the development of a tourism is influenced by the potential of the tourist attraction offered and the amount of tourist demand. The tourism development factors described by Hardjowigeno and Widiatmaka (2017) are similar to the concept of supply and demand for tourism in Hall and Page (2006). 


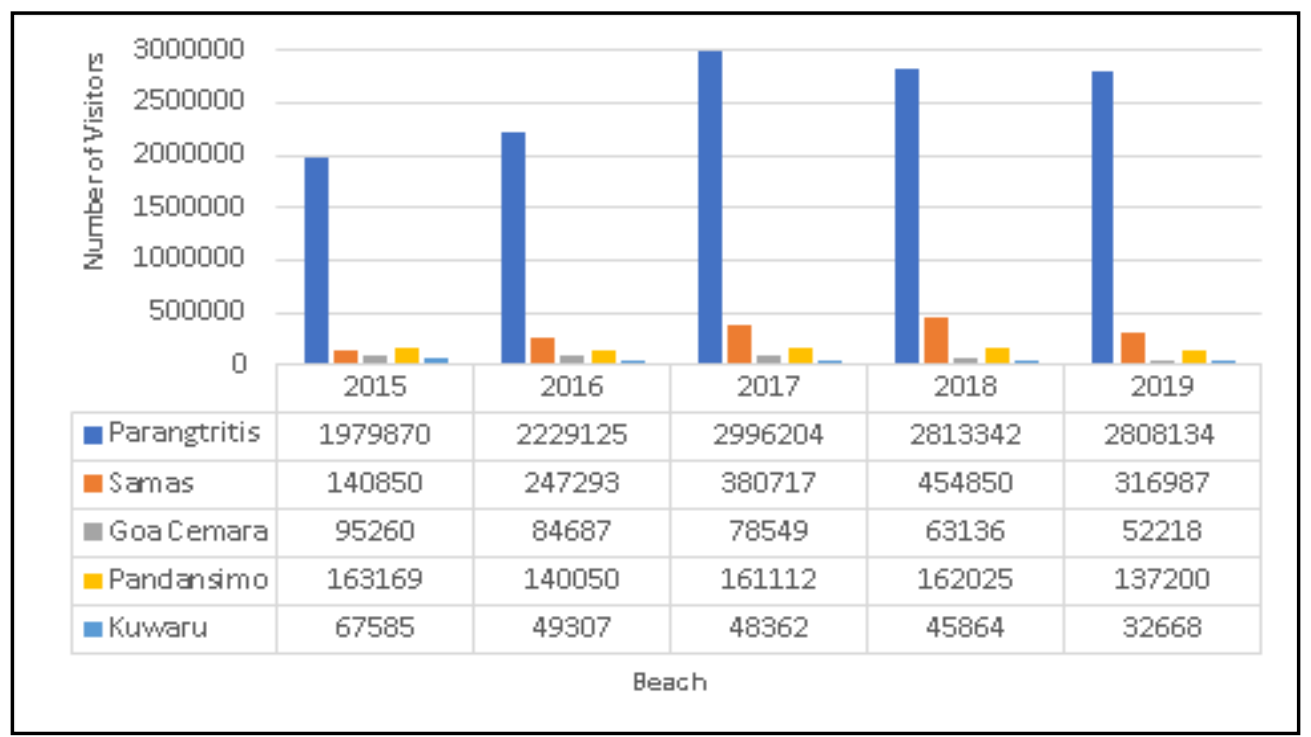

Figure 2. Number of Visitors to Beach Tourism Objects in Bantul Regency 2015-2019 (BPS Kabupaten Bantul, 2020).

Flickr, a social media platform for photo hosting and sharing, contains diverse information that scholars can use in scientific analysis and decision-making. In the case of tourism in Bantul Regency, the availability of this big data needs to be assessed to obtain relevant beach tourism information for future management. The issue of representation between social media users (netizens) and real tourists (Wibowo, 2017), position accuracy (Zielstra and Hochmair, 2013), and geotagged photos overlay (Carrion et al., 2017) are separate discussion outside the scope of the study. Each of the local beaches offers its characteristic attractions that tourists can enjoy and immortalize through photos. Travel photos shared on Flickr depict tourists' impression of a beach tour (Donaire et al., 2014), potentially influencing other users to travel (Briassoulis, 2002; Hall and Page, 2006). Apart from where and when the photos were taken (photo distribution patterns), gathering information on what and how they were captured is also necessary. This process, known as image content analysis, involves a systematic observational research method to identify and interpret the symbolic content of all forms of recorded communication (Hall and Valentin, 2005). Categorization was used to organize content analysis and a series of parameters and appropriate rules were established to maintain the suitability and validity of the data (Kolbe and Burnett, 1991). Donaire et al. (2014) differentiated photo contents by theme, level of human presence, image magnification, and indoor or outdoor attraction to determine tourist clusters. Themes provide information about which type(s) of attractions tourists are interested in, which can help target specific tourist market segments and advance tourism development. This study was designed to formulate recommendations for beach tourism management in Bantul Regency based on the popularity analysis of attraction using photos on Flickr.

The systematic writing of this research includes the first section explaining the background, research problems, and research objectives. The second section describes the research location and research stages, starting from Flickr scraping, patterns and density analysis, image content analysis, and recommendations for beach tourism management. The third section explains the results and discussion of research in the form of Flickr photo scraping, Flickr photo distribution patterns, the level of popularity of beaches, beach tourist attractions, and beach tourism 
management. The fourth section describes the research conclusions and suggestions for future research.

\section{Research Method}

The beach in Bantul Regency was chosen as the research location for several reasons, namely one of the tourist destinations with the highest tourist visits and variations of attractions on each beach. The population as well as the unit of analysis in this study is the beach in Bantul Regency. There are 18 tourism beaches that were identified (Table 1), but not all of them were analyzed due to the data availability on Flickr social media for each beach. A beach is an area, but has no physical boundaries. This makes it difficult to carry out an area-based analysis because the beach representation is displayed with point data. The location of beach coordinates is obtained from the Google Maps website (https:/ / google. com/maps).

Photo data from Flickr social media is downloaded by accessing the Flickr API (https://www.flickr.com/services/api/) and running the Flickr-Scrape script (https:// github.com/antiboredom/flickr-scrape) on Command Prompt. Photo searches were carried out using the keyword name of beaches in Bantul Regency (Table 1). An example of writing a script at the Command Prompt for scraping Flickr photo data can be seen in Figure 3.
Photos that were successfully downloaded from Flickr and had geolocation coordinates were selected. Geotagged photo selection is done in ArcGIS 10.5 software using the 'geotagged photos to points' command. Photos from Flickr have geographic coordinates (GCS). To do spatial analysis, the photo coordinates must be in meters (UTM coordinates) (Kisilevich et al., 2010), so the photos coordinates need to be converted. These geotagged photos were analyzed for spatial distribution pattern with the average nearest neighbor (ANN) and photo density with kernel density analysis (the grid size was adjusted to the observed mean distance derived from the ANN). The level of popularity of beaches was determined based on the photo density classification. A beach captured in a large number of photos has a high photo density and is deemed popular (Kisilevich et al., 2010; Majid et al., 2015; Vu et al., 2015; Peng and Huang, 2017). The photo density was classified using the natural break method (Manepalli et al., 2011) into three popularity classes: low, moderate, and high. The principle of this classification method is to group data into several classes based on the 'natural' categorization of the data. The boundaries between classes are identified from the best scores that are able to group similar values and maximize differences between classes so that the boundaries between classes are firm (Esri, 2016).

Table 1. List of tourist beaches in Bantul Regency.

\begin{tabular}{|c|c|c|c|c|c|}
\hline Sub-District & Kretek & & Sanden & & Srandakan \\
\hline Village & Parangtritis & Tirtohargo & Srigading & Gadingsari & Poncosari \\
\hline \multirow[t]{6}{*}{ Beach } & Parangtritis & Baros & Samas & Dewaruci & Segoro Kidul \\
\hline & Parangkusumo & & & $\begin{array}{l}\text { Hutan } \\
\text { Cemara }\end{array}$ & Cangkring \\
\hline & Cemara Sewu & & & Pandansari & Cemara Udang \\
\hline & Pelangi & & & Goa Cemara & Kuwaru \\
\hline & Depok & & & Patihan & Baru \\
\hline & & & & & Pandansimo \\
\hline
\end{tabular}


Anaconda Prompt (Anaconda2)

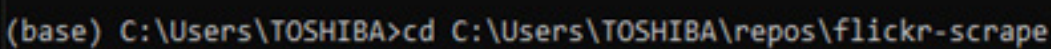

(base) C: UUsers\TOSHIBA\repos \flickr-scrape>python scraper.py --search "parangtritis" --original --max-pages 1000 --start-page $\theta$--bbox "110.191078 -8.044785 110.345468 -7.942354"

Figure 3. Script for Scraping Flickr Photos with the Keyword "parangtritis" in the Command Prompt.

Table 2. Categorization Scheme of Tourist Attraction Types.

\begin{tabular}{ll}
\hline \multicolumn{1}{c}{ Type of Tourist Attraction } & \multicolumn{1}{c}{ Description } \\
\hline Natural beauty & Natural landscapes, flora and fauna \\
History & Historical buildings and monuments \\
Culture & Local culture, traditions and festivals \\
Tourist Services & Public infrastructure, public facilities, and tourism facilities \\
\hline
\end{tabular}

Source: Perda Kabupaten Bantul No 18/2015, Donaire et al. (2014).

Referring to the variable used in Donaire et al. (2014), this research analyzed the image content using only one observable variable, namely the type of attraction, to obtain data of the photographed object and the impression of social media users about the pictured beach. The categorization scheme for this variable combines the Tourism Development Master Plan of Bantul Regency (RIPPARDA) and Donaire et al. (2014). Photos that did not contain any coastal attraction according to the scheme in Table 2 (for example abstract photos and photos of people) were classified as others. The content analysis of the photo here is limited to the image seen, not the message implied from the photo (Angus et al., 2010). Furthermore, if there is more than one type of attraction in one photo, the dominant one was selected.

The level of popularity represents tourism demand, while the attraction represents tourism supply. The popularity level of beach tourist attraction is obtained from the combination of the tourist beach popularity level map and the type of tourist attraction map. The map presents information on the distribution of beach tourist attraction types with a level of popularity. Information on the level of popularity and type of attraction acts as a strength (strength) as well as a weakness (weakness) for beaches. By knowing what type of attraction a beach are and which locations are popular for these types of beach tourist attraction, recommendations for beach tourism management can be proposed based on the concept of tourism supply and demand.

\section{Results and Discussion}

\subsection{Flickr Photos Scraping}

Photo scraping was carried out twice in 2020, on May 29 at 05:30 p.m. and August 16 at 11:00 a.m. The procedures conducted in this process follow academic ethical standards (Mancosu and Vegetti, 2020) because the information that is scraped is only photo id, photo, photo shoot date, and photo location. No personal user information is downloaded. The two-time scraping resulted in different numbers of photos because their owners deleted, added, or changed the privacy settings after the first scraping. The number of photos that can be scraped is different from the number of photos from the search results (see Table 3). This is because the search results with keywords also contain videos, and photos that can be downloaded are only photos with their public privacy settings. 
Table 3. Number of Flickr Photos per Tourist Beach in Bantul Regency.

\begin{tabular}{clccc}
\hline No & \multicolumn{1}{c}{ Beach } & $\begin{array}{c}\text { Searched } \\
\text { Photos }\end{array}$ & $\begin{array}{c}\text { Downloaded } \\
\text { Photos }\end{array}$ & $\begin{array}{c}\text { Geotagged } \\
\text { Photos }\end{array}$ \\
\hline 1 & Parangtritis & 5.795 & 3.416 & 70 \\
2 & Parangkusumo & 762 & 650 & 2 \\
3 & Cemara Sewu & 28 & 23 & 1 \\
4 & Pelangi & 573 & 427 & 0 \\
5 & Depok & 640 & 591 & 3 \\
6 & Baros & 50 & 20 & 14 \\
7 & Samas & 916 & 77 & 0 \\
8 & Dewaruci & 1 & 0 & 0 \\
9 & Hutan Cemara & 1 & 1 & 0 \\
10 & Pandansari & 46 & 45 & 0 \\
11 & Goa Cemara & 133 & 124 & 2 \\
12 & Patihan & 1 & 1 & 0 \\
13 & Segoro Kidul & 1 & 1 & 0 \\
14 & Cangkring & 0 & 0 & 0 \\
15 & Cemara Udang & 2 & 2 & 0 \\
16 & Kuwaru & 163 & 147 & 0 \\
17 & Baru & 57 & 32 & 0 \\
18 & Pandansimo & 82 & 43 & 0 \\
\hline Total & & 9.251 & 5.600 & 92 \\
\hline & & & & \\
\hline
\end{tabular}

This process was followed by preprocessing stage, including removing duplicates and selecting photos that met a predefined criterion, i.e., containing geolocation coordinates (Donaire et al., 2014). The search results on Flickr came back with 9,251 photos, and of the 5,600 successfully downloaded photos $(60.53 \%$ of the number of search result photos), 92 ( $0.99 \%$ of the number of search result photos) had geolocation coordinates showing only six beaches, namely Parangtritis, Parangkusumo, Cemara Sewu, Depok, Baros, and Goa Cemara. None of which were identical (duplicates), even though some were spatially overlapping. Furthermore, because the 92 geotagged photos had the same format, *.jpg, data format modification prior to the spatial analysis was unnecessary (Kisilevich et al., 2010).

\subsection{Flickr Photos Pattern}

The spatial distribution of geotagged photos on the tourist beaches of Bantul Regency is shown in Figure 4. Photos are an approach in representing the locations of tourists, although there is a position error that is influenced by GPS accuracy (Zielstra and Hochmair, 2013). Each beach has its own characteristics and unique charms so that it becomes a consideration for tourists when visiting beaches. The geotagged photos processed in this research are primarily of Parangtritis, Parangkusumo, Goa Cemara, Cemara Sewu, Baros, and Depok, implying that these beaches had a relatively high number of visitors. Tourists on Parangtritis, Parangkusumo, and part of Goa Cemara were mainly distributed close to the shorelines, while those on the other part of Goa Cemara and Cemara Sewu were further away from the beach because there were other tourist attractions besides the sea: Australian pine or whistling pine trees (Casuarina equisetifolia) and dunes. Tourists on Baros Beach tended to form clusters because the attractions were scattered at different sites with limited areas, 
such as mangroves that could only grow in certain locations. On Depok Beach, tourists were distributed in many cultural attractions, including the fish auction market, culinary establishments, and runways. By using geotagged Flickr photos, tourist distribution can be understand, but to obtain information on conditions in the field, a survey is still needed with the distribution of observation samples considering Flickr photos as complementary data (Ghermandi and Sinclair, 2019). Thus, social media is not only a means of promoting tourism, but also for understanding tourist behavior.

Flickr photos with the assumption that they represent tourists finally cannot represent all actual tourists who visit beaches. This can be seen from the comparison with the data on the number of visitors to beach attractions according to BPS Kabupaten Bantul (2016), the number of Flickr photos on Goa Cemara Beach is only $0.002 \%$ (the number of visitors to Goa Cemara Beach in 2014 was 88,909 visitors), while the number of Flickr photos in Parangtritis Beach is only 0.000006\% compared to the data on the number of visitors to the Parangtritis Beach according to BPS Kabupaten Bantul (2020) which was 2,996,204 visitors in 2017. However, information about the location of these tourists can be used as input for managers to pay more attention to tourism facilities at these locations because these locations are visited by many tourists so that tourist needs can be met. The tourism facilities in question can be in the form of infrastructure for tourism and disaster mitigation, considering that the southern coast of Bantul Regency is a disaster-prone area. For locations that are few visited by tourists, this is also an evaluation for managers of why the area is quieter with visitors compared to other areas. Through this research, it can be proven that Flickr provides a relatively long database $(\mathrm{Li}$ et al., 2018), which is 9 years and it is easy to access Flickr photos (Ghermandi and Sinclair, 2019), but the number of geotagged photos is only $0.99 \%$ of the number of all photo search results, unlike what Bae and Yun (2017) stated that Flickr has dominant geotagged photo data.

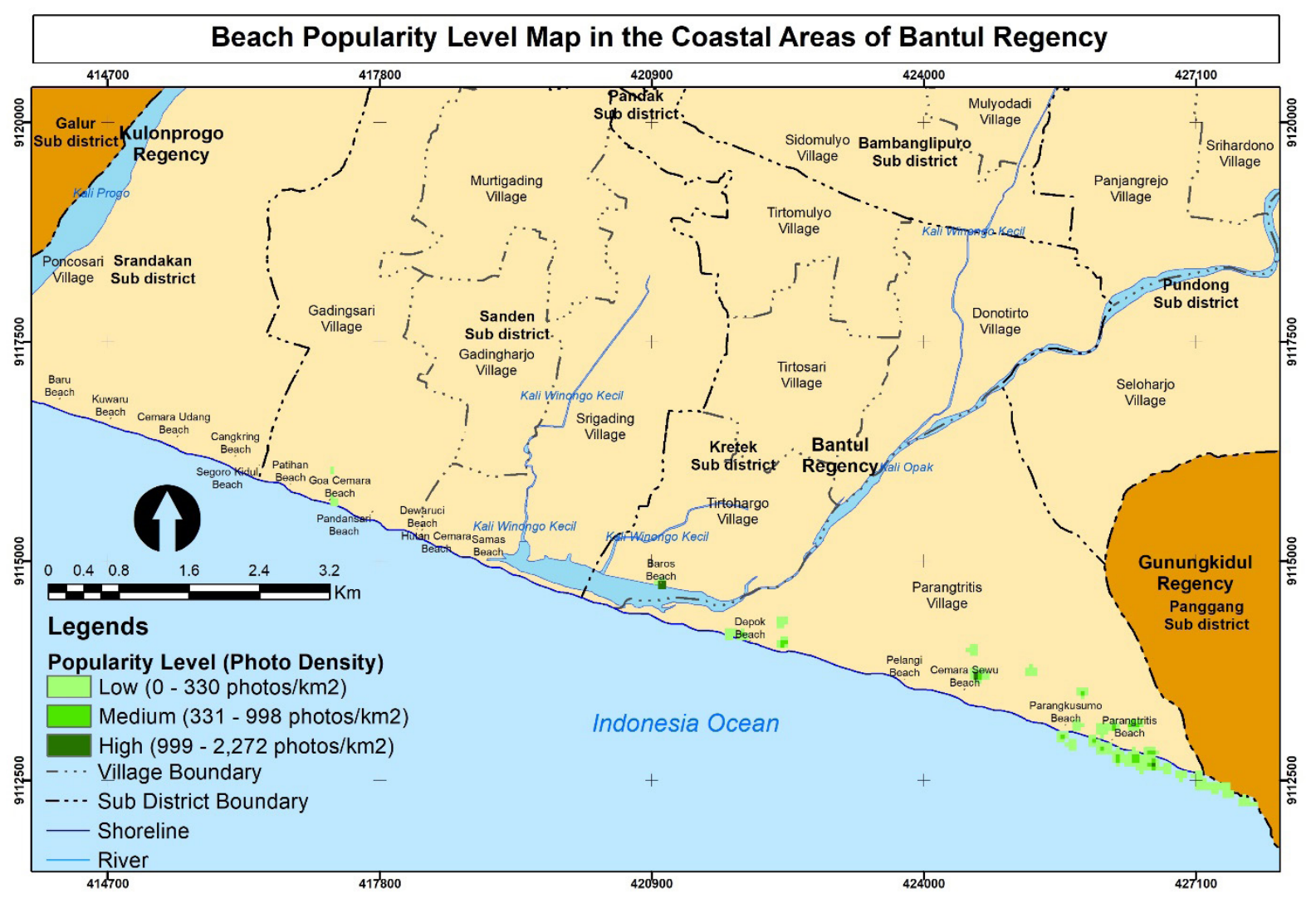

Figure 4. Flickr Photos Distribution Map (Tourists Representation) in the Coastal Areas of Bantul Regency. 
The pattern is calculated using a flat distance (euclidean distance) with the neighbor photo being considered is 1 photo. The results of the distribution pattern of Flickr photos from ANN at the study site showed a clustered pattern, with the closest distance between photos being 0 , the mean distance between photos was about $44.15 \mathrm{~m}$ as in Figure 5 , and the farthest distance between photos was $549.33 \mathrm{~m}$. The calculation of the ANN yielded a value of $0.30(<1.00)$, indicating a clustering pattern. It is the ratio of the observed mean distance (i.e., $44.15 \mathrm{~m}$ ) to the expected mean distance (i.e., $145.18 \mathrm{~m}$ ). The estimated distance is the average distance between photos in a hypothetical random distribution. In the ANN statistic, the null hypothesis (H0) is that the object follows a random distribution pattern, meaning that it is assumed that Flickr photos are taken randomly across beaches.

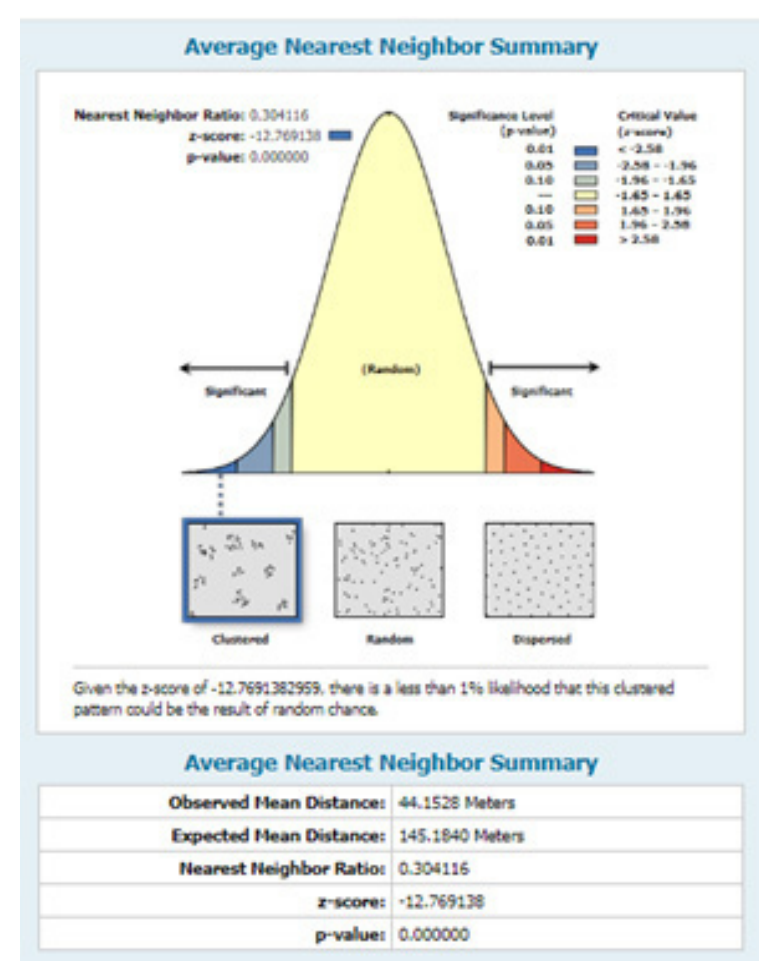

Figure 5. ANN Results: Spatial Distribution Patterns Photo Flickr.

The conclusion drawn on this hypothesis can be seen by looking at the z-score and p-value in Figure 5, where the z-score shows the value of -12.77 and the p-value is 0.000 . This means that it is less likely $(<1 \%)$ that the distribution pattern of Flickr photos is generated from a random process ( $\mathrm{H} 0$ is rejected). This clustering pattern indicates that the locations where the Flickr photos were taken are close to each other and more popular than other beaches that offer different attractions with smaller group markets. However, it should be noted that the ANN method is very sensitive to the wide area of the observation. The ANN results in Figure 5 are calculated by involving all Flickr photos of beaches in Bantul Regency. If the ANN process is carried out at each tourist beach or per coastal district administration, the distribution patterns obtained may be different.

\subsection{The Popularity of the Beaches}

Figure 6 shows a location that is more densely populated with Flickr photos (tourist representation) than the other locations. This is seen as a location with potential for economic activity, but on the other hand is seen as a location with the potential for victims of disaster and pollution. The highest density was 2,272 photos per $\mathrm{km} 2$, which is the estimated value of the actual number of photos on a 2,025 m2 grid. The photo density was grouped using the natural break method into three classes of popularity: high, moderate, and low. Baros, Cemara Sewu, and Parangtritis had a high density, indicating high popularity. Parangkusumo, Depok, and several locations on Parangtritis and Cemara Sewu had moderate level of popularity. Baros, Goa Cemaran, and some sites on Parangtritis, Parangkusumo, Cemara Sewu, and Depok had low popularity. Field observation on October 31, 2020, which coincided with a long holiday, confirmed the analysis results that some locations at the six beaches observed are 
indeed crowded. The underlying reason is believed to be the availability of tourist facilities (Floris and Campagna, 2014). For instance, on Parangtritis Beach, tourists are concentrated at various locations where a variety of tourist facilities are located, forming a scattered pattern along the coast. On the contrary, the limited facilities on Parangkusumo Beach and dunes make them less visited by tourists. Kisilevich et al. (2010) stated that the popularity of a tourism destination varies in time depending on weather conditions, crowd-drawing events (sports and festivals), and time of the year (high or low season, weekdays or holidays). Therefore, adequate tourist facilities with diverse establishments will increase tourist arrivals and the popularity of the beaches.

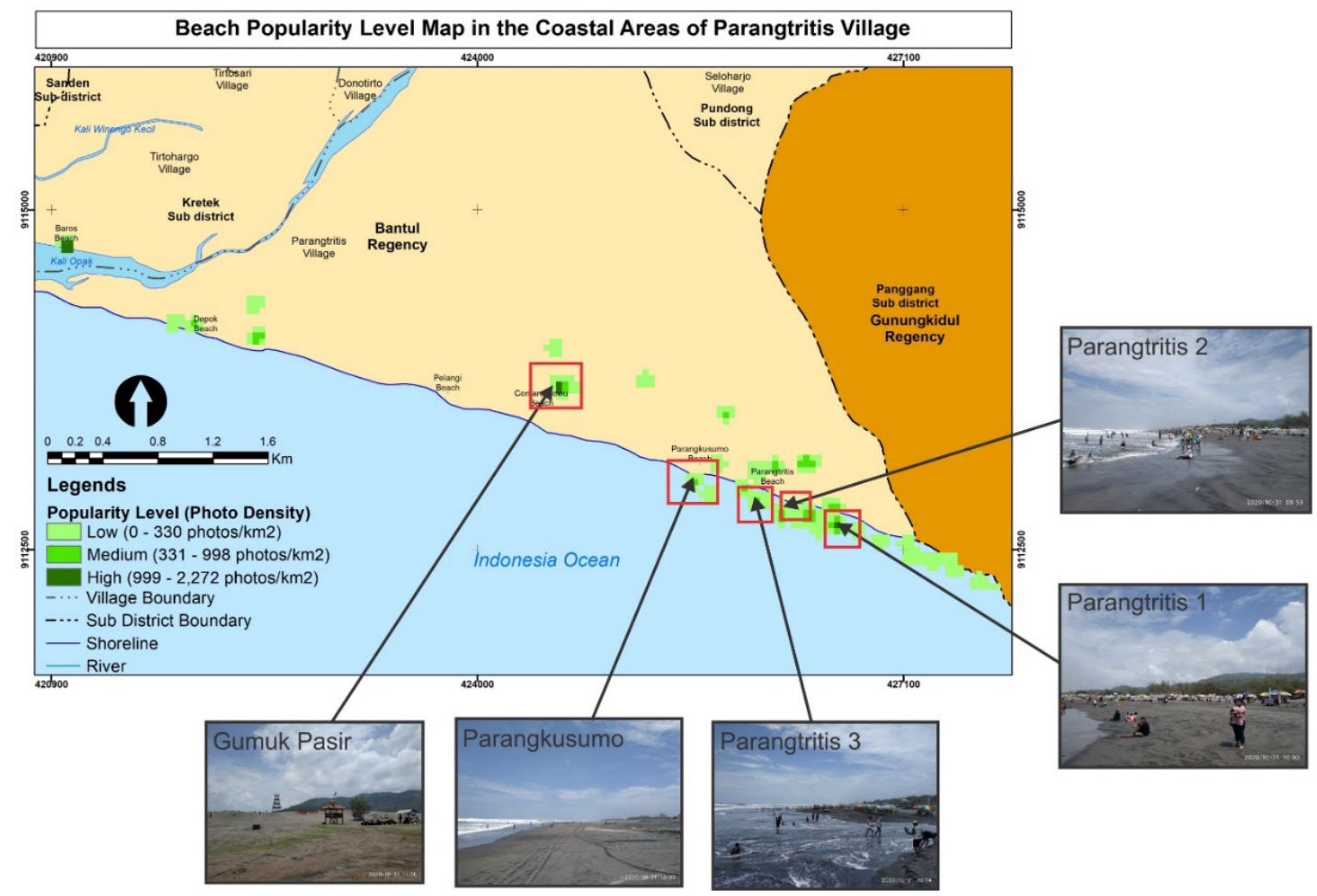

Figure 6. Flickr Photo Density Map with Kernel Density Method and Classification of Popularity Levels in the Coastal Areas of Bantul Regency (Photographed by the author in 2020).

\subsection{Coastal Tourist Attractions}

Table 4 presents 5 Flickr photos as examples of descriptions of image content analysis. The number of geotagged Flickr photos per attraction category is presented in Table 5. while the percentage of attraction types for geotagged Flickr photos is presented in Figure 7. Coastal attractions in Bantul Regency based on the geotagged Flickr photos are dominated by natural attractions (48 photos or $52 \%$ ), followed by the class 'others' (20 photos or $22 \%$ ) and tourist services (16 photos or
$17 \%)$. Meanwhile, culture and history were the least photographed features, i.e., seven photos of culture $(8 \%)$ and one photo of history $(1 \%)$, indicating the least popular attractions. Because tourists' impression of the local beaches is generally based on natural beauty, this attractive feature should be the first target or priority in tourism development. Apart from enjoying the view, tourists can also do other activities to gain experience from other attractions and feel comfortable during their visits because of adequate and diverse tourist facilities. 
Table 4. Description of Flickr Image Content Analysis (Photographed by the author in 2020).

\begin{tabular}{|c|c|c|c|c|}
\hline No & Flickr Photo & Location & Description & $\begin{array}{c}\text { Beach Attraction } \\
\text { Class }\end{array}$ \\
\hline 1 & & Goa Cemara & $\begin{array}{l}\text { Scenery of prawn pine } \\
\text { (Casuarina equisetifolia), waves, } \\
\text { sea foam, and black beach sand }\end{array}$ & Natural beauty \\
\hline 2 & & Parangtritis & $\begin{array}{l}\text { The landmark reads } \\
\text { "Parangtritis Beach" }\end{array}$ & History \\
\hline 3 & & Parangkusumo & $\begin{array}{l}\text { Hindu religious events } \\
\text { welcoming the Silent Day of } \\
\text { Saka New Year } 1935\end{array}$ & Culture \\
\hline 4 & & Parangtritis & $\begin{array}{l}\text { Wagon transportation services } \\
\text { to get around Parangtritis Beach }\end{array}$ & Tourist Services \\
\hline 5 & & Parangtritis & Students who are traveling & Others \\
\hline
\end{tabular}

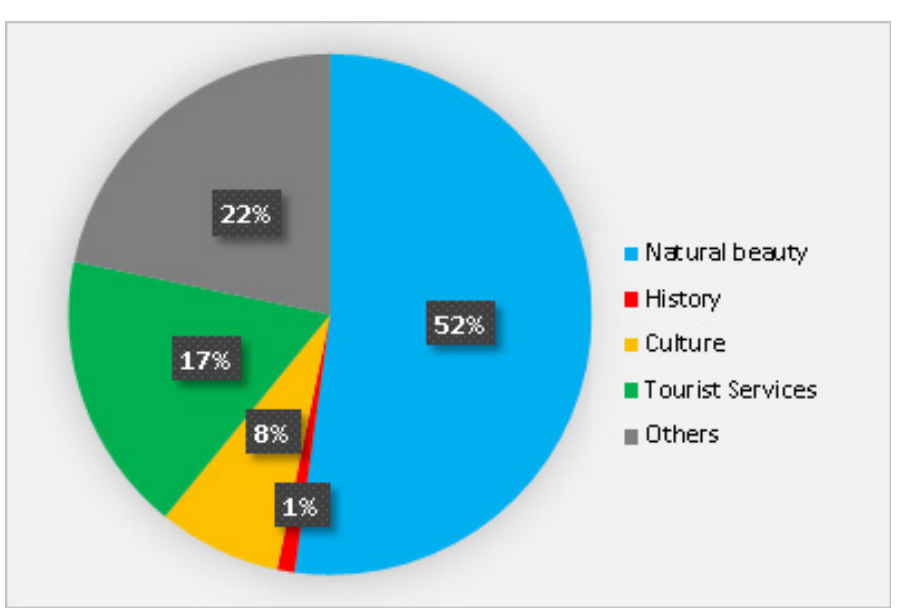

Figure 7. Percentage of Geotagged Flickr Photos per Tourist Attraction Category. 
Table 5. Number of Tourism Beach Geotagged Flickr Photos per Tourist Attraction Category.

\begin{tabular}{|l|c|c|c|c|c|c|}
\hline \multicolumn{1}{|c|}{ Beach } & $\begin{array}{c}\text { Natural } \\
\text { Beauty }\end{array}$ & History & Culture & $\begin{array}{c}\text { Tourist } \\
\text { Service }\end{array}$ & Others & Total \\
\hline Parangtritis & 39 & 1 & 0 & 14 & 16 & 70 \\
\hline Parangkusumo & 2 & 0 & 0 & 0 & 0 & 2 \\
\hline Depok & 2 & 0 & 0 & 1 & 0 & 3 \\
\hline Goa Cemara & 2 & 0 & 0 & 0 & 0 & 2 \\
\hline Baros & 2 & 0 & 7 & 1 & 4 & 14 \\
\hline Cemara Sewu & 1 & 0 & 0 & 0 & 0 & 1 \\
\hline Total & 48 & 1 & 7 & 16 & 20 & 92 \\
\hline
\end{tabular}

Parangtritis Beach has a number of geotagged photos of 70 photos, the most among other tourist beaches, with details of attraction consisting of 39 photos with the theme of natural beauty, 1 photo themed history, 14 themed photos of tourist services, and 16 photos of other classes. According to tourist uploaded photos, attraction is dominated by the theme of natural beauty, then other class themes, and tourist services so that the impression that Parangtritis Beach has is a beach that offers an atmosphere of natural beauty of the beach, supported by the availability of tourism facilities to serve tourists and support other activities, including tourism with historicalthemed. Parangkusumo Beach has 2 geotagged photos, consisting of 2 photos with the theme of natural beauty. According to photos uploaded by tourists, attraction is dominated by the theme of natural beauty so that it gives the impression that Parangkusumo Beach is a beach that offers an atmosphere of natural beauty. This does not represent the actual attraction where historical-themed tourism is more recognized by the presence of Cepuri and various activities / traditions at certain times held at Parangkusumo Beach. Cemara Sewu Beach has a number of geotagged photos of 1 photo with the theme of natural beauty so that it gives the impression that Cemara Sewu Beach is a beach that offers an atmosphere of natural beauty. This is quite representative of attraction because it offers attraction, namely the natural beauty of the whistling pine trees.
However, there are other tourist attractions, namely various tourism facilities, ranging from meeting halls, camping places, sports fields, and ATV rentals so that it can be said that tourists who come to visit Cemara Sewu Beach can enjoy various activities and services.

Depok Beach has 3 photos with 3 coordinates, consisting of 2 photos with the theme of natural beauty and 1 photo on the theme of tourist services. According to tourist uploaded photos, attraction is dominated by the theme of natural beauty so that it gives the impression that Depok Beach is a beach that offers an atmosphere of natural beauty of the beach and is supported by the availability of tourism facilities to serve tourists. This does not represent the actual attraction where culinary-themed tourism is better known on Depok Beach with the existence of fish auction places, fish markets, and food stalls with seafood menus. Baros Beach has 14 geotagged photos, consisting of 2 photos with the theme of natural beauty, 7 photos on cultural themes, 1 photo themed on tourist services, and 4 photos with the theme of other classes. According to tourist uploaded photos, attraction is dominated by cultural themes, then other class themes, natural beauty, and tourism services so that the impression that Baros Beach has is a beach that offers a tradition / culture of mangrove planting, an atmosphere of natural beauty of mangrove forests, supported by the availability of ecotourism facilities for the sake of serve 
tourists and support other activities. Goa Cemara Beach has a number of geotagged photos of 2 photos with the theme of natural beauty so that it gives the impression that Goa Cemara Beach is a beach that offers an atmosphere of natural beauty of the beach. This is quite representative of attraction because it offers attraction, namely natural beauty in the form of whistling pine trees. However, there are other tourist destinations, namely various tourism facilities, ranging from swimming pools, hatchlings and food stalls, so tourists who come to visit Goa Cemara Beach can enjoy various activities and services.

The distribution of beach tourist attraction types in Bantul Regency is presented in Figure 8. It can be seen that the natural beauty of the attraction is found in all tourist beaches that have geotagged photos
(Parangtritis, Parangkusumo, Cemara Sewu, Depok, Baros, and Goa Cemara Beach). Most of these photos are located on the waterfront and in some places further inland. The geotagged photos also showed that the six beaches offered natural beauty as their attractions. The natural coastal attractions include the view of the sea, cliffs, sand, and sunset on the beach, while, on the landward side, there are coastal vegetation, dunes, and some spots where tourists can view the beach panorama with wider coverage. In addition, historical attractions, tourist services, and other attractive features (the class 'others') are scattered along the coast; the last two features are also found further inland. This means that the tourist facilities are available for use and that tourists can do various activities other than seeing the natural beauty of the beaches.

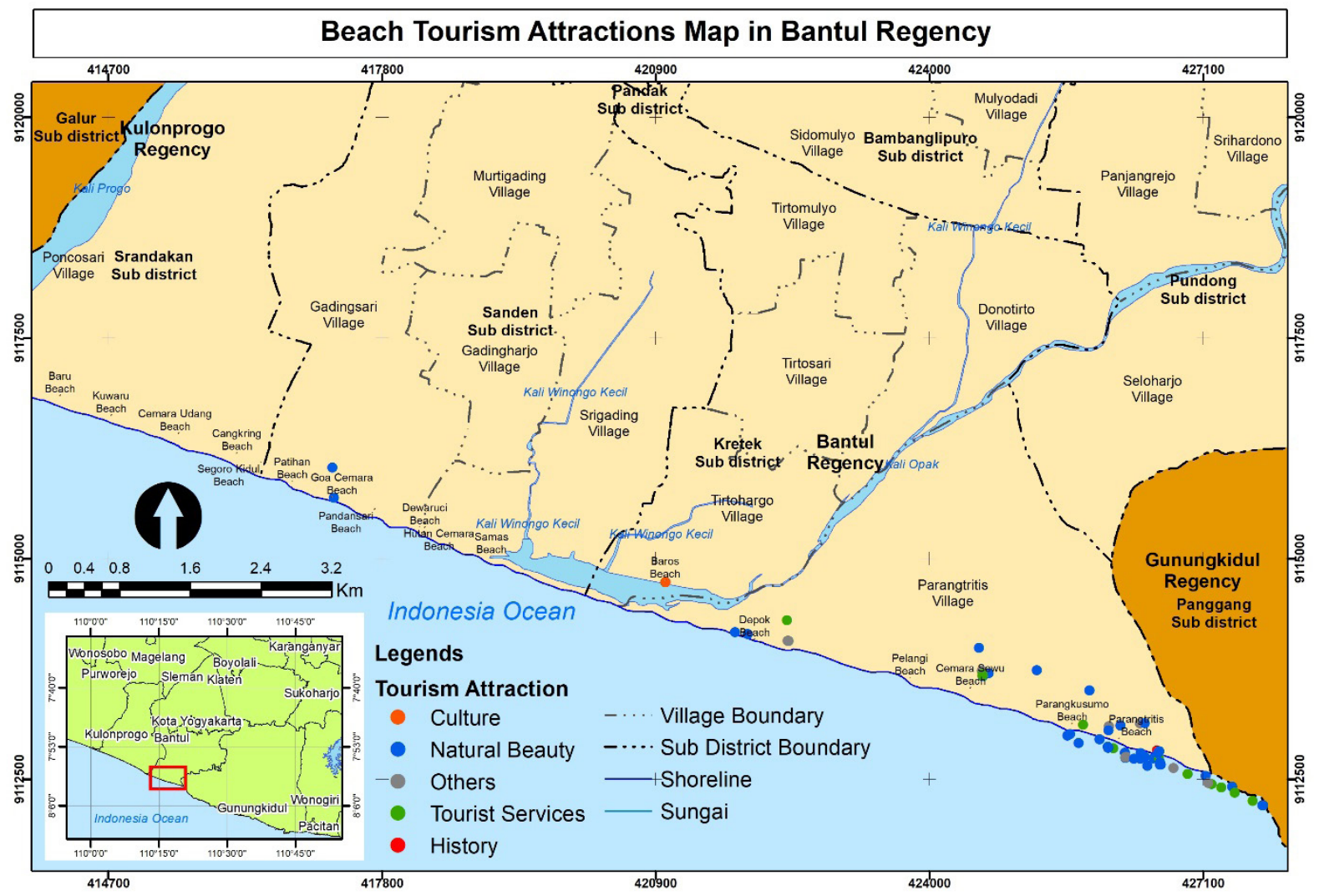

Figure 8. Beach Tourist Attractions Map in Bantul Regency. 
Several beach locations have photos that overlap with the same or different attraction categories. For locations with several photos that have the same attraction category, this strengthens the evidence that the attraction category is the potential of the tourist beach so that it needs to be developed, for example several places on Parangtritis and Parangkusumo Beaches which have a collection of photos that overlap with the attraction category in the form of natural beauty. Efforts to develop the potential of natural beauty, for example by building photo spots or arranging land so that locations that are favorite photo spots for tourists are not obstructed. The cleanliness of the beach is also one aspect that needs to be considered in order to maintain the beauty of the beach. For locations with several photos but having different attraction categories, this shows that tourists can get various attractions on one beach and each of these attractions has its own advantages for tourists, but its role is the same, namely increasing tourist visits to these tourist beaches. Examples are at Cemara Sewu, Baros, Parangkusumo, and several places on Parangtritis Beach. Different categories of attraction in one location can be a combination of natural beauty-others, natural beautyhistory, natural beauty-tourist service, natural beauty-culture, others-culture, culture-tourist services, and others- tourist services.

\subsection{Beach Tourism Management Based on the Popularity of Tourist Attractions}

Figure 9 showed the combination of the tourist beach popularity level map and the type of tourist attraction map. Parangtritis, Parangkusumo, Cemara Sewu, and Depok Beaches offer natural beauty and provide adequate services and various other activities for tourists. These beaches can be managed together because they have the same type of attraction and are administratively located in one subdistrict, Parangtritis. Meanwhile, Baros needs to have a unique form of management because the attractive feature it offers, namely mangrove ecotourism, are different from the other beaches. Even though Goa Cemara has the same attraction as Baros, it requires separate management because they are located in different subdistrict, Gadingsari and Tirtohargo, respectively. In general, each of the six beaches observed in this research offers a variety of attractions that tourists can choose for their visits. However, some only offer specific features, for example, natural attraction on Goa Cemara and cultural attraction on Baros, meaning that tourists only have a few options to explore when traveling to these beaches. Nevertheless, Baros offers specific tours and targets certain tourist segments, making the cultural attraction popular and tourists' demand for visiting the beach quite high (supply is small but demand is clear).

Beaches such as Parangtritis, Depok, Parangkusumo, and Cemara Sewu with various attractions, on the one hand, are said to have quite complete attractions in terms of tourism supply (high supply), but what needs to be considered is whether the offer has fulfilled tourist demand or not. Beach management should follow a direction that suits the tourism theme, which is reflected by the attraction's popularity. Popularity analysis showed high demands for the tourist services and other attractions on Cemara Sewu and natural attractions on Parangtritis and moderate demands for natural attractions on Parangkusumo and Depok. Therefore, it is necessary to plan the typical attractions of a beach so that the tourism management can focus on the popular theme to increase tourist arrivals. Apart from looking at what tourist beaches have to offer and what tourists are asking for, it is also important to know how the supply and demand is spread. Parangtritis has attractions scattered along the coast with variations in tourist demand, while other beaches tend to have a centralized attraction (Figure 9). This distribution affects the ease of managing tourist beaches, where if the distribution of the attraction is centralized it tends to be easier to manage than the scattered attractions. Planning for tourism and disaster facilities needs to adjust to the distribution of tourists, which is related to the distribution of attraction. 


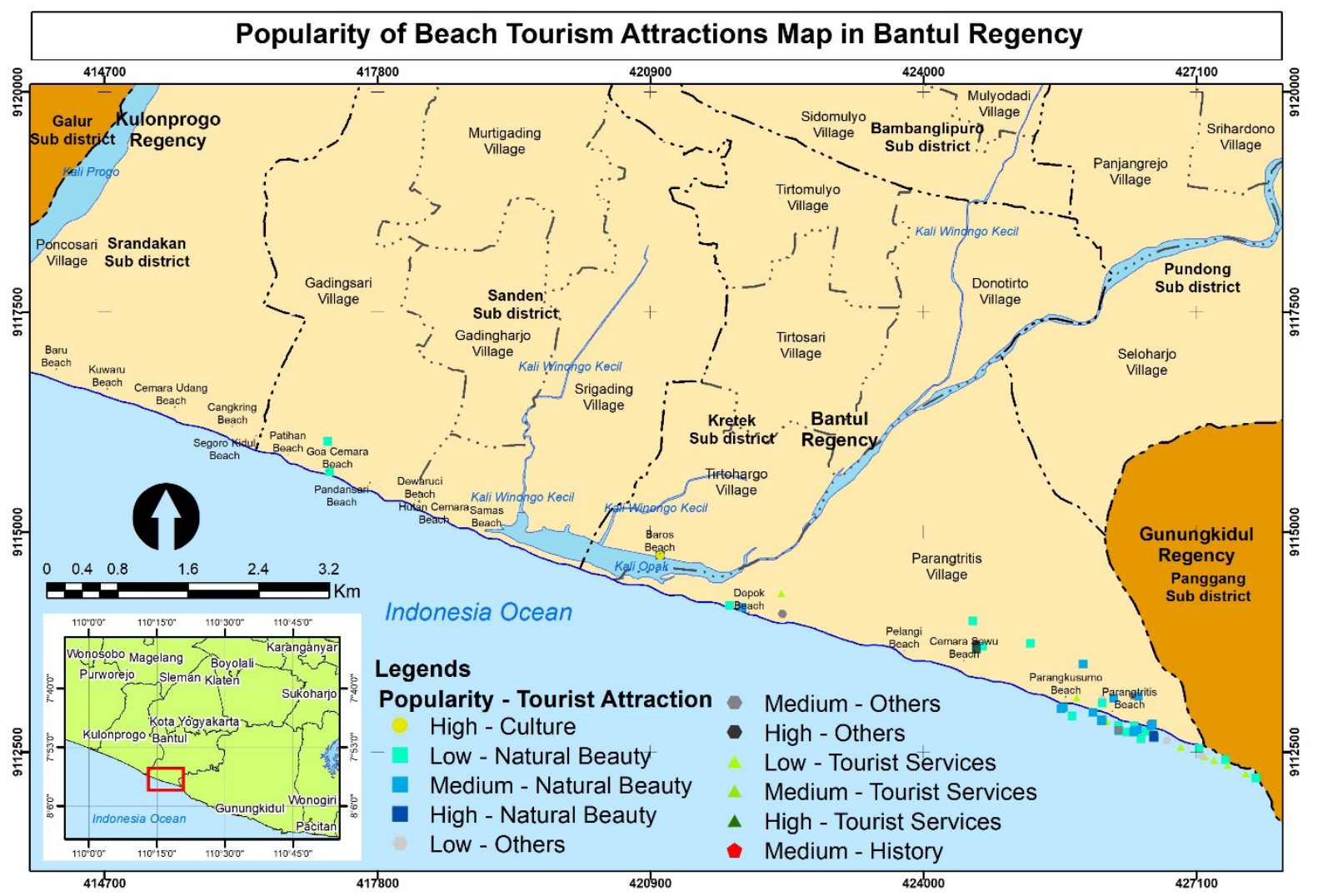

Figure 9. Popularity of Beach Tourist Attractions Map in Bantul Regency.

\section{Conclusion}

This study examines the availability of geotagged Flickr photo data to assist in making beach tourism management policies. Although the geotagged photos are only $0.99 \%$ of the image search results on Flickr, they can explain the distribution patterns of tourists and the popularity of the pictured beaches. In addition, photos that are shared by users on social media can be analyzed the content to determine the attractiveness of beach tourism. Tourists are clustered at several beaches of high popularity: Parangtritis, Baros, Depok, and Cemara Sewu. Natural beauty is the main tourist attraction of all beaches in Bantul Regency, except Baros Beach (the main attraction is culture). By using the geotagged Flickr photo data and refers to the concept of tourism supply and demand, the research recommends managing and developing coastal tourist attractions according to their respective themes and levels of popularity. Further studies are needed regarding the separation of tourists and nontourists, types of local and foreign tourists, analysis of travel motivation, and types of accommodation and tourist transportation (flow map). Image content analysis can use several aspects of observation besides the theme of the photo, such as human presence, photo enlargement, indoor / outdoor.

\section{Acknowledgements}

This research was fully funded by Universitas Gadjah Mada Final Project Recognition scheme in 2020 (No. 2607/UN1/ DITLIT/DIT-LIT/PT/2020). The authors would like to thank the Faculty of Geography, Universitas Gadjah Mada for all the facilities and assistance that support this research activity. The author would also like to thank Azis Musthofa, S.Si. and Luthfi Hakim Mufadhol, S.Si. who has provided some input in Flickr image content analysis and preparing this research design. 


\section{References}

Alonso-Almeida, M. del M., Borrajo-Millán, F., \& Yi, L. (2019). Are social media data pushing overtourism? The case of Barcelona and Chinese Tourists. Sustainability, 11(12), 1-17. https:// doi.org/10.3390/SU11123356

Angus, E., Stuart, D., \& Thelwall, M. (2010). Flickr's potential as an academic image resource: An exploratory study. Journal of Librarianship and Information Science, 42(4), 268-278. https:/ / doi.org/10.1177/0961000610384656

Bae, S. H., \& Yun, H. J. (2017). Spatiotemporal Distribution of Visitors' Geotagged Landscape Photos in Rural Areas. Tourism Planning and Development, 14(2), 167-180. https:/ / doi.org/1 $0.1080 / 21568316.2016 .1204356$

Briassoulis, H. (2002). Sustainable tourism and the question of the commons. Annals of Tourism Research, 29(4), 1065-1085. https:// doi.org/10.1016/S0160-7383(02)00021-X

BPS Kabupaten Bantul. (2016). Kabupaten Bantul Dalam Angka 2016. Bantul: BPS Kabupaten Bantul.

BPS Kabupaten Bantul. (2020). Kabupaten Bantul Dalam Angka 2020. Bantul: BPS Kabupaten Bantul.

Camprubí, R., Guia, J., \& Comas, J. (2013). The new role of tourists in destination image formation. Current Issues in Tourism, 16(2), 203-209. https://doi.org/10.1080/13683500.2012.733 358

Carrion, D., Migliaccio, F., \& Pagliari, D. (2017). Exploring geolocation issues in social media analytics : A case study with Tweet messages. Sixth International Virtual Scientific Conference on Informatics and Management Sciences, 100-103.

Castro, C. B., Martín Armario, E., \& Martín Ruiz, D. (2007). The influence of market heterogeneity on the relationship between a destination's image and tourists' future behaviour. Tourism Management, 28(1), 175-187. https:// doi.org/10.1016/j.tourman.2005.11.013

Chung, J. Y., \& Buhalis, D. (2008). Web 2.0: A Study of Online Travel Community. In P. O'Connor, W. Hopken, \& U. Gretzel (Eds.), Information and Communication Technologies in Tourism 2008 (pp. 70-81). https://doi.org/10.1017/CBO9781107415324.004

Dinas Pariwisata DIY. (2018). Arahan Pengembangan Kawasan Pariwisata D.I. Yogyakarta. Yogyakarta.

Dinas Pariwisata DIY. (2019). Statistik Kepariwisataan 2018. Yogyakarta: Dinas Pariwisata DIY.

Ding, X., \& Fan, H. (2019). Exploring the distribution patterns of Flickr photos. ISPRS International Journal of Geo-Information, 8(418), 1-15.

Donaire, J. A., Camprubí, R., \& Galí, N. (2014). Tourist clusters from Flickr travel photography. Tourism Management Perspectives, 11, 26-33. https:/ / doi.org/10.1016/j.tmp.2014.02.003

Esri. (2016). ArcGIS 10.5 Help. Redlands: Environmental System Research Institute.

Floris, R., \& Campagna, M. (2014). Social media data in tourism planning: analysing tourist's satisfaction in space and time. Proceedings Real Corp, 8(May), 997-1003.

Garrod, B. (2009). Understanding the relationship between tourism destination imagery and tourist photography. Journal of Travel Research, 47(3), 346-358. https://doi. org/10.1177/0047287508322785

Ghermandi, A., \& Sinclair, M. (2019). Passive crowdsourcing of social media in environmen- 
tal research : A systematic map. Global Environmental Change, 55(September 2018), 36-47. https:// doi.org/10.1016/j.gloenvcha.2019.02.003

Hall, C M, \& Valentin, A. (2005). Content Analysis. In B. W. Ritchie, P. Burns, \& C. Palmer (Eds.), Tourism Research Methods: Integrating Theory with Practice (pp. 191-209). Oxfordshire: CABI Publishing.

Hall, C Michael, \& Page, S. J. (2006). The Geography of Tourism and Recreation: Environment, Place and Space. In (Geography of tourism). (3rd ed.). New York: Routledge.

Hardjowigeno, S., \& Widiatmaka. (2017). Evaluasi Kesesuaian Lahan dan Perencanaan Tataguna Lahan. Yogyakarta: Gadjah Mada University Press.

Kisilevich, S., Krstajic, M., Keim, D., Andrienko, N., \& Andrienko, G. (2010). Event-based analysis of people's activities and behavior using Flickr and Panoramio geotagged photo collections. 14th International Conference Information Visualisation, 289-296. https://doi.org/10.1109/ IV.2010.94

Kolbe, R. H., \& Burnett, M. S. (1991). Content-Analysis Research: An Examination of Applications with Directives for Improving Research Reliability and Objectivity. Journal of Consumer Research, 18(2), 243-250.

Li, J., Xu, L., Tang, L., Wang, S., \& Li, L. (2018). Big data in tourism research : A literature review. Tourism Management, 68, 301-323. https:// doi.org/10.1016/j.tourman.2018.03.009

Lo, I. S., McKercher, B., Lo, A., Cheung, C., \& Law, R. (2011). Tourism and online photography. Tourism Management, 32(4), 725-731. https:// doi.org/10.1016/j.tourman.2010.06.001

MacKay, K. J., \& Couldwell, C. M. (2004). Using visitor-employed photography to investigate destination image. Journal of Travel Research, 42(4), 390-396. https://doi. org/10.1177/0047287504263035

Majid, A., Chen, L., Mirza, H. T., Hussain, I., \& Chen, G. (2015). A system for mining interesting tourist locations and travel sequences from public geo-tagged photos. Data $\mathcal{E}$ Knowledge Engineering, 95, 66-86. https:// doi.org/10.1016/j.datak.2014.11.001

Manepalli, U. R. R., Bham, G. H., \& Kandada, S. (2011). Evaluation of hotspot identification using kernel density estimation $(\mathrm{K})$ and getis-ord $\left(\mathrm{Gi}^{*}\right)$ on I-630. 3rd International Conference on Road Safety and Simulation, 1750, 1-17. Indianapolis Indiana.

Mancosu, M., \& Vegetti, F. (2020). What you can scrape and what is right to scrape: A proposal for a tool to collect public Facebook data. Social Media + Society, July-September 2020: 1-11. https:/ / doi.org/10.1177/2056305120940703

Parra-Lopez, E., Gutierrez-Tano, D., Diaz-Armas, R. J., \& Bulchand-Gidumal, J. (2012). Travellers 2.0: Motivation, Opportunity and Ability to Use Social Media. In M. Sigala, E. Christou, \& U. Gretzel (Eds.), Social Media in Travel, Tourism and Hospitality: Theory, Practice and Cases (p. 339). Farnham: Ashgate Publishing.

Peng, X., \& Huang, Z. (2017). A novel popular tourist attraction discovering approach based on geo-tagged social media big data. ISPRS International Journal of Geo-Information, 6(216), 1-16. https:// doi.org/10.3390/ijgi6070216

Peraturan Daerah Kabupaten Bantul Nomor 18 Tahun 2015 tentang Rencana Induk Pembangunan Kepariwisataan Daerah Tahun 2015-2025.

Rofi, A., Wibowo, T. W., Sudaryatno, \& Farda, N. M. (2019). Tourists geovisualization analysis utilizing Instagram data in Central Java Province and Special Region of Yogyakarta. The 
International Archives of the Photogrammetry, Remote Sensing and Spatial Information Sciences, XLII-4(W16), 535-542. Kuala Lumpur.

Safitri, H., \& Pramono, AH. (2009). Refleksi atas gerakan pemetaan partisipatif dan tantangan dimasa depan (Reflection on the Participatory Mapping Act and Future Challenges). In AH. Pramono, F. Samperante, H. Safitri, R. Achmaliadi (Eds), Menuju Demokratisasi Pemetaan: Refleksi Gerakan Pemetaan Partisipatif di Indonesia (Toward Mapping Democratisation: Reflections on the Participatory Mapping Act in Indonesia. Bogor: Jaringan Kerja Pemetaan Partisipatif (JKPP).

Stock, K. (2018). Mining location from social media: A systematic review. Computers, Environment and Urban Systems, 71, 209-240. https:/ / doi.org/10.1016/j.compenvurbsys.2018.05.007

Stylianou-Lambert, T. (2012). Tourists with cameras: Reproducing or Producing? Annals of Tourism Research, 39(4), 1817-1838. https:/ / doi.org/10.1016/j.annals.2012.05.004

Tenkanen, H., Di Minin, E., Heikinheimo, V., Hausmann, A., Herbst, M., Kajala, L., \& Toivonen, T. (2017). Instagram, Flickr, or Twitter: Assessing the usability of social media data for visitor monitoring in protected areas. Scientific Reports, 7(1), 1-11. https://doi.org/10.1038/ s41598-017-18007-4

Thelwall, M. (2018). Social media analytics for YouTube comments: potential and limitations. International Journal of Social Research Methodology, 21(3), 303-316. https:// doi.org/10.1080 /13645579.2017.1381821

Urry, J., \& Larsen, J. (2011). The tourist gaze 3.0. In Antropólogos Iberoamericanos en Red (3rd ed., Vol. 09). https://doi.org/10.11156/240

Vu, H. Q., Li, G., Law, R., \& Ye, B. H. (2015). Exploring the travel behaviors of inbound tourists to Hong Kong using geotagged photos. Tourism Management, 46, 222-232. https://doi. org/10.1016/j.tourman.2014.07.003

Wibowo, T W. (2017). Spatial point data analysis of geolocated Tweets in the first day of Eid AlFitr 2017 in Java Island. Fifth Geoinformation Science Symposium 2017, 1-10. Yogyakarta: IOP Publishing.

Wibowo, T W, Rofi, A., \& Sulistyaningrum, N. A. (2019). Density analysis of Flickr data as a proxy to reveal the intensity of tourism activity in Borobudur. Sixth Geoinformation Science Symposium 2019, (11311), 1-8. https:/ / doi.org/10.1117/12.2549040

Yan, Y., Eckle, M., Kuo, C., Herfort, B., Fan, H., \& Zipf, A. (2017). Monitoring and assessing post-disaster tourism recovery using geotagged social media data. ISPRS International Journal of Geo-Information, 6(144), 1-17. https://doi.org/10.3390/ijgi6050144

Yudono, A. (2017). Towards democracy in spatial planning through spatial information built by communities: The investigation of spatial information built by citizens from participatory mapping to volunteered geographic information in Indonesia. 3rd International Conference of Planning in the Era of Uncertainty, 012002, 1-16. https://doi.org/10.1088/17551315/70/1/012002

Zielstra, D., \& Hochmair, H. H. (2013). Positional accuracy analysis of Flickr and Panoramio images for selected world regions. Journal of Spatial Science, 58(2), 251-273. https://doi.org/1 $0.1080 / 14498596.2013 .801331$ 